\title{
Central Precocious Puberty in a Three-Year-Old Girl
}

\author{
Suryani Jamal ${ }^{1}$, Liong Boy Kurniawan ${ }^{1}$, Suci Aprianti ${ }^{1}$, Ratna Dewi ${ }^{2}$, Ruland DN. Pakasi ${ }^{1}$, \\ R. Satriono ${ }^{2}$ \\ ${ }^{1}$ Department of Clinical Pathology, Faculty of Medicine, Hasanuddin University/Dr. Wahidin Sudirohusodo Hospital, Makassar, Indonesia. \\ E-mail: suryani.jamal@gmail.com \\ ${ }^{2}$ Department of Pediatrics, Faculty of Medicine, Hasanuddin University/Dr. Wahidin Sudirohusodo Hospital, Makassar, Indonesia
}

\begin{abstract}
Precocious puberty is defined as the onset of secondary sexual characteristics before 8 years of age in girls and 9 years in boys. Central Precocious Puberty (CPP) is caused by early activation of the hypothalamic-pituitary-gonadal axis. Laboratory test of $\mathrm{LH}, \mathrm{FSH}$, and Estradiol is recommended for monitoring suppressive effects from GnRHa therapy in the early three months and every six months. This study aimed to report a case of CPP in a 3-year and 3-month-old girl. A 3-year and 3-month-old girl went to the hospital with vaginal bleeding (menstruation), breast development, and pubic and axilla hair for 7-month-old. Physical examination found moderately ill with obesity, body weight $20 \mathrm{~kg}$, height $98 \mathrm{~cm}$. Tanner stage was A2M3P2, café au lait was found in the left forehead with size 7x3.5 cm. In March 2015 before GnRHa therapy, LH, FSH and Estradiol level increased with levels of $4.32 \mathrm{mlU} / \mathrm{mL}, 6.01 \mathrm{mlU} / \mathrm{mL}$, and $67 \mathrm{pg} / \mathrm{mL}$, and after $3 \mathrm{months}$ of the treatment was $0.87 \mathrm{mlU} / \mathrm{mL}, 2.51 \mathrm{mlU} / \mathrm{mL}$ and $<20 \mathrm{pg} / \mathrm{mL}$. Pelvic ultrasonography showed suggestive precocious puberty, bone age 5-year and 9-month (Greulich and Pyle), CT-Scan of the brain showed hypothalamic tumor suspected hypothalamic hamartoma. This patient was treated with a GnRHa injection every 4 weeks. Leuprorelin is a synthetic non-peptide analogue of natural $\mathrm{GnRH}$. The diagnosis was based on medical history, physical examination, laboratory, and radiological findings. The prognosis of the patient was good.
\end{abstract}

Keywords: Precocious puberty, central precocious puberty, laboratory monitoring, GnRH agonist

\section{INTRODUCTION}

Precocious puberty is defined as a condition when secondary sexual development occurs before age 8 in girls and before age 9 in boys. Precocious puberty is classified into two as follows: central precocious puberty (GnRH-dependent precocious puberty) and peripheral precocious puberty $(\mathrm{GnRH}$-independent precocious puberty). Clinical manifestations of precocious puberty depend on the duration of symptoms, onset and progression of physical development, the existence of linear growth acceleration, and advanced bone age. It is important to emphasize that the diagnosis of precocious puberty is not only based on signs of early secondary sex development, but also clinical, hormonal, and radiological evidence of progress. If precocious puberty has been diagnosed, its type must be determined (central or peripheral precocious puberty). If necessary, the underlying disease is diagnosed to determine the appropriate therapy. ${ }^{1,2}$ Types of precocious puberty: Central precocious puberty (GnRH-dependent precocious puberty). $\mathrm{GnRH}$-dependent precocious is caused by early activation of the hypothalamic-pituitary gonadal-axis of which gonadotropin secretion is physiologically stimulated by hypothalamic GnRH secretion. This precocious puberty can occur due to Central Nervous System (CNS) abnormalities that disrupt the balance between inhibitory and stimulatory factors that control the onset of puberty, puberty development, and idiopathic; Peripheral precocious puberty ( $\mathrm{GnRH}$-independent precocious puberty) is caused by the stimulation of sex steroid hormones and is not affected by the secretion of the pituitary gonadotropins. Sex steroid hormones can come from endogenous sources (gonadal and extragonadal) or exogenous sources. Endogenous sex steroid hormones are produced autonomously or are caused by gonadotropins that are not produced by the pituitary or activation of gonadotropin receptors. ${ }^{3}$

GnRH-dependent precocious puberty is the central type of precancerous disease that is disrupted, which stimulates the premature release of gonadotropin. From research conducted by Carel and Léger in 2008, the cause of this precocious puberty was still idiopathic (92\% of cases in females and 50\% of cases in males); however, there was a possibility of 
genetic factor. In addition, the remaining cases of central type precocious puberty are caused by lesions in the CNS. Some lesions that can cause central precocious puberty are as follows: Hypothalamic hamartoma, a benign lesion or tumor in the hypothalamus. These lesions can cause various disorders concerning the activity of the hypothalamus, which functions as the body's autonomous center. Symptoms that arise from this disease include seizures, precocious puberty, cognitive deterioration, and behavioral symptoms commonly known as rage behavior; Gliomas, a brain tumor that occurs due to abnormal growth of glial cells (nerve supporting cells). ${ }^{3}$

The purpose of the FSH and $\mathrm{LH}$ test is to determine the function of hormone secretion released by the hypothalamus and physiological feedback mechanisms from testes and ovaries as the target organs. Follicle Stimulating Hormone (FSH) levels will increase in hypogonadism, precocious puberty, menopause, failure of testicular differentiation, orchitis, seminoma, acromegaly, Turner syndrome, hypothalamic insufficiency, gonadal dysfunction, anovulation, hypophyses insufficiency, and ovarian tumors. Factors affecting levels are drugs such as steroids, oral contraceptives, progesterone, estrogen, and testosterone. ${ }^{4}$

Interpretation of hormonal test is not only according to the standard values, but also a comparison between one hormone and another, and other important data such as signs of puberty, heterosexual features, hirsutism, history of treatment or action, which can interfere with the development and function of sexual and reproductive organs, a family history of abnormalities in sexual immaturity and infertility, menstrual problems, a history of excessive activity, heavy weight loss, and unusual dietary patterns, as well as data from physical examination, which assesses the biological effects of hormones in the body such as height, weight, body mass index, breast development and other symptoms such as galactorrhea, distribution and amount of body hair as well as other symptoms of hirsutism. ${ }^{5}$

Central precocious puberty therapy is $\mathrm{GnRH}$ agonist $(\mathrm{GnRHa})$ therapy that works by eliminating the effect of $\mathrm{GnRH}$ stimulus on gonadotropin synthesis and release. Leuprorelin is a synthetic non-peptide analogous to natural GnRH. Long-term use of leuprorelin leads to decreased gonadotropin secretion, primarily suppressing testicular function in males and inducing uterine atrophy and ectopic endometrial tissue in females. This effect can be stopped with drug therapy. Within 2-4 weeks with adequate treatment, the average $\mathrm{LH}$ response to $\mathrm{GnRH}$ in the prepubertal range and the level of sex steroids is suppressed in 4-12 weeks. Decreased secondary sex characteristics and decreased growth velocity and bone age were demonstrated during the first year of therapy. Menarche and ovulatory cycles in females generally appear within 6-18 months of therapy. ${ }^{4,5}$

Regular evaluation is important to monitor the adequacy and effectiveness of treatment. Height, weight, growth speed, and Tanner staging (as shown in Table 1) at puberty must be measured. Other measurements such as bone age, basal sex steroids, $\mathrm{LH}, \mathrm{FSH}$, and Estradiol are also recommended to

Table 1. Phases of breast and pubic hair development according to Tanner ${ }^{6}$

\begin{tabular}{|c|c|}
\hline Stage & Female Breast Development Scale \\
\hline M1 & No palpable glandular breast tissue \\
\hline M2 & Palpable breast bud under the areola (1st pubertal sign in females) \\
\hline M3 & Palpable breast tissue outside the areola, no areolar development) \\
\hline M4 & $\begin{array}{l}\text { Areola elevated above the contour of the breast, forming a "double } \\
\text { scoop" appearance }\end{array}$ \\
\hline M5 & $\begin{array}{l}\text { Areolar mound recedes into a single breast contour with areolar } \\
\text { hyperpigmentation, papillae development, and nipple protrusion }\end{array}$ \\
\hline Stage & Pubic Hair Scale (both males and females) \\
\hline P1 & No hair \\
\hline P2 & Downy hair \\
\hline P3 & Scant terminal hair \\
\hline P4 & Terminal hair that fills the entire triangle overlaying the pubic region \\
\hline P5 & Terminal hair that extends beyond the inguinal crease onto the thigh \\
\hline
\end{tabular}


monitor the immediate suppression of hormones in the first 3 months and every 6 months. Termination of $\mathrm{GnRH}$ therapy mainly depends on the main goal of therapy, one of which is to prevent shortening of height in adulthood. The parameters for this purpose are chronological age of 11 years, or according to bone age of 12-12.5 years. Other objectives including the reduction of psychosocial distress and child retardation development. In the central precocious that is treated with $\mathrm{GnRHa}$, a better prognosis will be obtained if treated early.,

\section{CASE}

A girl, with the age of 3 years 3 months went to Dr. Wahidin Sudirohusodo Hospital, Makassar in September 2014 from Pelamonia Hospital, Makassar with main complaints of bleeding in the vagina and enlarged breasts.

\section{ANAMNESIS}

A girl, 3 years 3 months went to the hospital with the main complaint of bleeding from the vagina (menstruation) since she was 1 year 6 months every month, with a length of about 3-4 days and in 1 day the patient can change sanitary pad up to 2 times. Enlarged breasts were observed since the age of 7 months. Her underarm hair and genitals have grown 2 months before hospitalization. There were no complaints of fever, convulsions, headaches, sight problems, coughing, or vomiting. The stool was normally yellow. The urine was yellow. The patient's mother experienced her first menstruation at the age of 14 years.

\section{GENERAL DESCRIPTION}

Moderate pain, obesity, conscious awareness, Glasgow Coma Scale (GCS) 15, with bodyweight: 20 kg, Height: $98 \mathrm{~cm}$, upper arm circumference: $17 \mathrm{~cm}$, head circumference: $49 \mathrm{~cm}$, chest circumference: $59 \mathrm{~cm}$, stomach circumference: $61 \mathrm{~cm}$, Body Mass Index $(B M I)=21.13 \%$, blood pressure $90 / 60 \mathrm{mmHg}$, pulse $128 x$ /minute, respiration $28 x$ /minute and temperature $37^{\circ} \mathrm{C}$.

Physical examination; lung bronchovesicular, ronchi, and wheezing were not found. An auscultation test revealed regular I/II heart sounds. Peristalsis was normal, the liver was not palpable. Lien was not palpable.

On physical findings (as shown in Figure 1); Axilla: visible fine hair, mammae: visible lumps, genitalia: visible fine hair, puberty status: A2M3P2. History of hospital treatment: intramuscular injection of Leuprorelin. History of maternal pregnancy: regular check for pregnancy at the hospital. Maternal birth history: normal childbirth helped by a doctor. History of parents: her father is 35-year-old and her mother is 27-year-old. The patient is the youngest, both sisters are healthy children.

\section{LABORATORY FINDINGS}

Complete blood count test (February 12, 2015): Hemoglobin $12.0 \mathrm{~g} / \mathrm{dL}$, hematocrit $34.8 \%$, MCV $81 \mathrm{fL}$, $\mathrm{MCH} 27.9 \mathrm{pg}, \mathrm{MCHC} 34.5 \mathrm{~g} / \mathrm{dL}$, leukocyte $9,500 / \mathrm{mm}^{3}$, platelets $116,000 / \mathrm{mm}^{3}$, neutrophils $40.5 \%$, lymphocytes $51.0 \%$, monocytes $6.0 \%$, eosinophils $1.7 \%$, basophils $0.8 \%$.
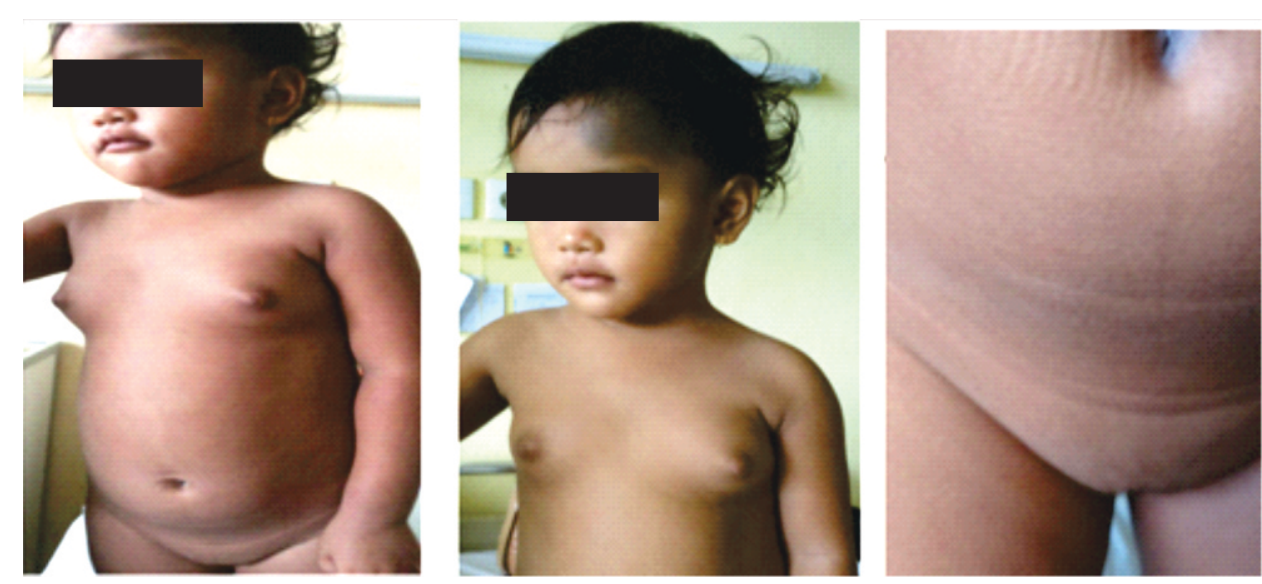

Figure 1. Precocious puberty patient before GnRHa therapy 


\section{Blood Chemistry Tests}

\begin{tabular}{|c|c|c|c|c|c|}
\hline & Blood Glucose & Prolactin & LH & FSH & Estradiol \\
\hline & $\mathrm{N}=100-200 \mathrm{mg} / \mathrm{dL}(<5$ y.o $)$ & $\begin{array}{l}\mathrm{N}=2-43 \mathrm{ng} / \mathrm{mL} \\
\text { (female } 1-3 \text { y.o) }\end{array}$ & $\begin{array}{l}\mathrm{N}=0.9-1.9 \mathrm{mIU} / \mathrm{mL} \\
\text { (female } 1-3 \text { y.o) }\end{array}$ & $\begin{array}{l}\mathrm{N}=0.67-3.3 \mathrm{mIU} / \mathrm{mL} \\
\text { (female1-3 у.о) }\end{array}$ & $\begin{array}{l}\mathrm{N}==53 \mathrm{pg} / \mathrm{mL} \\
\text { (female } 0-<6 \text { y.o) }\end{array}$ \\
\hline \multicolumn{6}{|l|}{ Date } \\
\hline $12 / 2 / 2015$ & $66 \mathrm{mg} / \mathrm{dL}$ & & & & \\
\hline $19 / 9 / 2014$ & & $11.1 \mathrm{ng} / \mathrm{mL}$ & & & \\
\hline $23 / 3 / 2015$ & & & $4.32 \mathrm{mIU} / \mathrm{mL}$ & $6.05 \mathrm{mIU} / \mathrm{mL}$ & 67 pg/mL \\
\hline 6/6/2015 & & & $0.87 \mathrm{mIU} / \mathrm{mL}$ & $2.51 \mathrm{mIU} / \mathrm{mL}$ & $<20.0 \mathrm{pg} / \mathrm{mL}$ \\
\hline
\end{tabular}

\section{Urinalysis (February 12, 2015)}

Yellow color, pH 6.0, specific gravity $\geq 1,030$, negative protein, negative glucose, negative blood, leukocytes $+/ 70$, leukocytes 2 fields of view, erythrocyte sediment 1 field of view.

\section{RADIOLOGY FINDINGS}

September 18, 2014; AP Manus Photo + Obliq D/S: Bone age was estimated at 5 years 9 months (according to Greulich and Pyle). September 18, 2014; Gynecological ultrasound: Based on the morphology and hemodynamics of the uterus, precocious puberty was suspected. October 2, 2014; MSCT Head (with contrast): Hypothalamic tumor suspected hypothalamic hamartoma.

\section{DISCUSSION}

A girl aged 3 years and 3 months, went to the hospital with complaints of vaginal bleeding (menstruation), enlarged breasts since the age of 7 months, and the growth of pubic hair and armpit hair since 2 months before admitted to the hospital. On physical examination, it was found: moderate pain, obesity, weight: $20 \mathrm{~kg}$, height: $98 \mathrm{~cm}$, Tanner A2M3P2 stadium, café au lait was found on the left forehead with a size of $7 \times 3.5 \mathrm{~cm}$. In March 2015 before GnRH agonist therapy, LH, FSH and Estradiol levels were high; $4.32 \mathrm{mlU} / \mathrm{mL}, 6.01 \mathrm{mlU} / \mathrm{mL}$ and 67 $\mathrm{pg} / \mathrm{mL}$ and after 3 months of GnRH agonist therapy, $\mathrm{LH}, \mathrm{FSH}$ and Estradiol levels decreased; $0.87 \mathrm{mlU} / \mathrm{mL}$, $2.51 \mathrm{mlU} / \mathrm{mL}$ and $<20 \mathrm{pg} / \mathrm{mL}$. Pelvic ultrasound examination showed a precocious puberty, bone age of 5 years 9 months (Greulich and Pyle), CT brain scan showed a hypothalamic tumor suspecting hypothalamic hamartoma.

In this case report the patient's laboratory test results were starting with laboratory test on 19 March 2014: Prolactin: 11.1 (2-43 ng/mL), 23 March 2015: LH: $4.32 \mathrm{mIU} / \mathrm{mL}$ (normal in female aged $1-3$ years: $0.9-$ $1.9 \mathrm{mIU} / \mathrm{mL}$ ), $\mathrm{FSH}$ : $6.01 \mathrm{mIU} / \mathrm{mL}$ (normal in female aged 1-3 years 0.67-3.3 mIU/mL), Estradiol: $67 \mathrm{pg} / \mathrm{mL}$ (normal in female aged $0-<6$ years: $\leq 53 \mathrm{pg} / \mathrm{mL}$ ), then patients were given Leuprorelin therapy at a dose of $11.25 \mathrm{mg} /$ intramuscularly. Furthermore, 6 June 2015: LH: $0.87 \mathrm{mIU} / \mathrm{mL}$ (normal in female aged 1-3 years: 0.9 to $1.9 \mathrm{mIU} / \mathrm{mL}$ ), $\mathrm{FSH}: 2.51 \mathrm{mIU} / \mathrm{mL}$ (normal in female aged 1-3 years: $0.67-3.3 \mathrm{mIU} / \mathrm{mL}$ ), Estradiol: $<20.0 \mathrm{pg} / \mathrm{mL}$ (normal in female aged $0-<6$ years: $\leq 53 \mathrm{pg} / \mathrm{mL}$ ), then the dose of Leuprorelin was reduced to $3.75 \mathrm{mg} /$ intramuscularly every three months.

Gonadotropin-Releasing Hormone agonist $(\mathrm{GnRHa})$ is the most effective therapy for central precocious puberty, working by eliminating the effect of the GnRH stimulus on gonadotropin synthesis and release (as shown in figure 2) .,5

The GnRHa therapy used is a leuprorelin acetate, with an initial dose of $100 \mu \mathrm{g} / \mathrm{kg} / \mathrm{month}$ via intramuscular or subcutaneous. The maintenance dose is $80-100 \mu \mathrm{g} / \mathrm{kg} / \mathrm{month}$ based on monitoring. ${ }^{4,5}$

Monitoring is carried out every 3-6 months after the onset of therapy. The things that need to be monitored to see the effectiveness of therapy are: Growth velocity of children; Characteristics of secondary sex, especially puberty status according to the Tanner scale, LH levels, testosterone/estradiol; Skeletal maturity or bone age. ${ }^{4,5}$

Bone Mineral Density (BMD) monitoring is not needed to monitor the effectiveness of therapy. If the suppression is not adequate during monitoring, the dose of $\mathrm{GnRHa}$ or its frequency of injection must be increased. If the growth velocity decreases, the dose of GnRHa must be decreased. ${ }^{4,5}$

The decision to terminate the therapy must be individualized and based on various factors, such as the growth velocity and bone age, chronological age according to the age of puberty, or when height is normal. In girls, therapy can be stopped if the age of the bones reaches the age of 12-12.5 years. The wishes of parents and the emotional maturity of children must be considered. In central precocious puberty treated with $\mathrm{GnRHa}$, the prognosis is better if therapy is started early. 


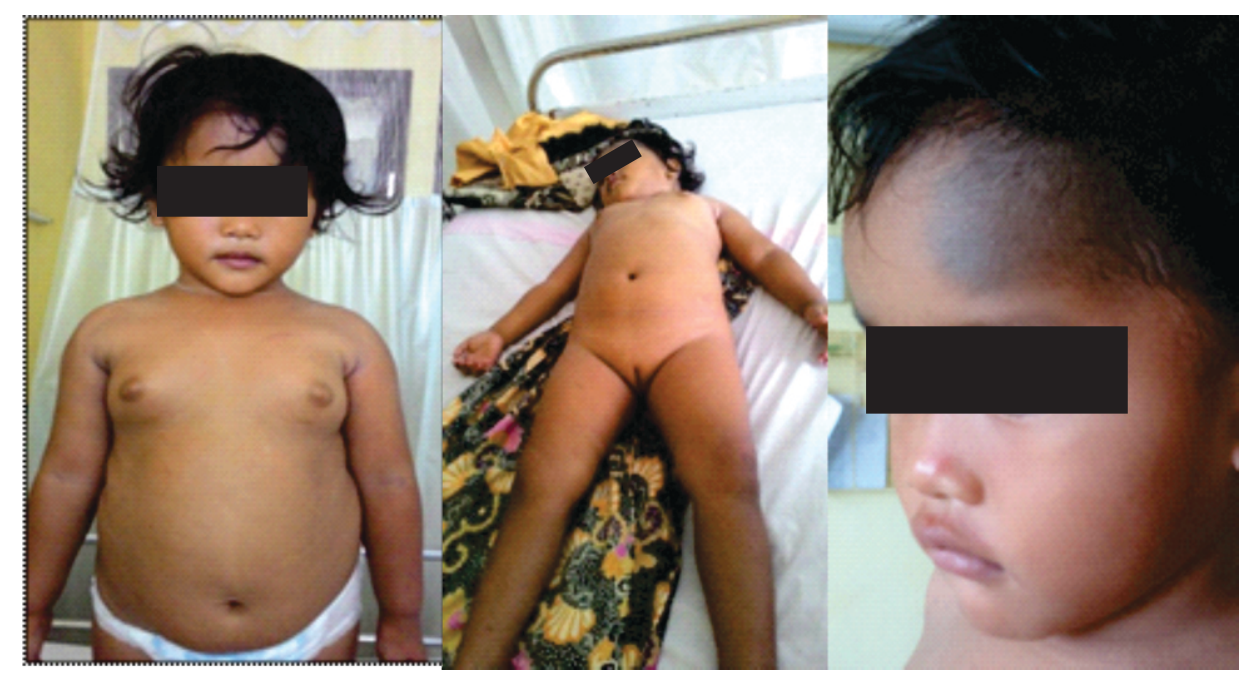

Figure 2. Precocious puberty patient after GnRHa therapy

\section{CONCLUSION}

This is a reported case of central precocious puberty in a girl with an age of 3 years old and 3 months. The diagnosis was made based on history, physical examination, laboratory tests, and radiology. The prognosis for this case was good.

\section{REFERENCES}

1. Coal JRL, Tridjaja B, Pulungan AB. Puberty and its disorders in children. Endocrinology textbook. Issue I. UKAI Child and Adolescent Endocrinology UKAI, 2015; 6: 85-104.

2. P Pallavee, Samal R. Precocious puberty: A clinical review. International Journal of Reproduction,
Contraception, Obstetrics and Gynecology, 2018; 7(3): 771-777.

3. Kiess W, Hoppmann J, Gesing J, Penke M, Korner A, et al. Puberty-genes, environment and clinical issues. J Pediatr Endocrinol Metab, 2016; 29(11): 1229-31.

4. Guaraldi F, Beccuti G, Gori D, Ghizzoni L. Management of endocrine disease: Long-term outcomes of the treatment of central precocious puberty. Eur J Endocrinol, 2016; 174(3): R79-87.

5. Latronico AC, Brito VN, Carel JC. Causes, diagnosis, and treatment of central precocious puberty. Lancet Diabetes Endocrinol, 2016; 4: 265-274.

6. Emmanuel M, Bokor BR. Tanner stages. In: StatPearls (Internet). Treasure Island, StatPearl Publishing, 2020. Available from: https://www.ncbi.nlm.nih. gov/books/NBK470280/2021 (accessed 18 Jan, 2020). 